\title{
Active yeast (Saccharomyces cerevisiae) supplementation improves digestibility of lamb diet ${ }^{1}$
}

\author{
M.S. Bueno ${ }^{2}$, M.H.T. Watanabe ${ }^{2}$, J. Issakowicz ${ }^{3}$, A.C.K. Sampaio ${ }^{3}$ \\ ${ }^{1}$ Financially supported by FAPESP $n^{\circ}$ 2008/06201-0 \\ ${ }^{2}$ Instituto de Zootecnia APTA/SAA-SP - Rua Heitor Penteado, 56 Nova Odessa, SP Brasil. 13460-000 \\ ${ }^{3}$ Universidade de São Paulo - Centro de Energia Nuclear na Agricultura,NAPTSA - Avenida Centenário, 303 \\ Piracicaba, SP Brasil. 13400-970
}

\begin{abstract}
The aim of the study was to evaluate the supplementation of active yeast (Saccharomyces cerevisiae) on diets of lambs fed with two different concentrate proportion on DM intake, apparent digestibility of nutrients, in vitro digestibility of dry matter and rumen fermentation parameters. Twenty non-castrated male lambs, averaging 120 days-old, housed in metabolism cages, with collector and separator of feces and urine fed with diets comprising grass hay and concentrate rations in two different proportion $(80 \%$ or $60 \%$, on DM basis), supplemented or not with active yeast (5 g/day) were used. Supplementation with active yeast increased $(p<0.05)$ apparent digestibility coefficient of DM, OM, CP, NDF, non-fibrous CHO and HEM, as well as, TDN values, with no significant effect $(P>0.05)$ on DM intake, independently of concentrate proportion. The rumen parameters were not changed by the active yeast supplementation since the rumen $\mathrm{pH}$ and ammonia nitrogen were similar between diets with or without active yeast. Values of in vitro digestibility of DM were higher for active yeast supplemented diets. Supplementation of diets of lambs with active yeast improves digestibility of $D M$ and fiber, regardless of concentrate proportion, without changing DM intake.
\end{abstract}

Keywords - probiotic, rumen ammonia, rumen $\mathrm{pH}$, rumen parameters, sheep

\section{INTRODUCTION}

Diets with high concentrate proportion are required to express the genetic potential for maximum live weight gain of lambs finished in confinement; however, it can cause great impact on rumen health. This type of diet leads to increased production of short chain fatty acids and lactate with decreasing $\mathrm{pH}$, which impairs the amount of cellulose-digesting bacteria and decreases digestibility of fiber and production of microbial mass [1]. Increase on cellulolytic bacterial population (Fibrobacter succinogenes, Ruminococcus albus and Ruminococcus flavefaciens) was observed by [2], with active yeast supplementation to lamb diets.

The mechanism of action of Saccharomyces cerevisiae in the rumen basically comprise the decrease of present oxygen that can affect rumen environment and utilization of food, as $\mathrm{pH}$ control, decrease in lactate production and stimulation of cellulose-digesting bacteria [3]. According to [4], supplementation of cow's diets with active yeast led to increased ruminal $\mathrm{pH}$, decreased lactate concentration and acetate : propionate ratio, but had no effect on ammonia $\mathrm{N}$ concentration and, thus, reduce the risk of rumen acidosis in commercial cattle.

In addition, besides effects regarding to the better performance of some types of bacteria, [3] pointed the supply of growth factors - vitamins (B complex, para-aminobenzoicacid, etc), dicarboxylic acids (fumarate, malate, etc) and the reduction in protozoa numbers, as possible beneficial effects.

[5] concluded that active yeast culture supplementation to finishing lambs fed high energy diets improves weight gain, feed-to-gain ratio and apparent digestibility of DM, OM, CP and NDF, although [6], through meta-analyze of several experiments published from 1990 to 2009, showed that addition of dry active $S$. cerevisiae yeast to sheep diets had effect for DM, OM and CP apparent digestibility, as well as, for rumen $\mathrm{pH}$ and had any effect on growth, feed conversion, ruminal parameters or fiber digestibility.

Thus, the use of active yeast can increase feeding efficiency and lead to increased sheep production.

The objective of the present experiment was to evaluate the effect of active yeast (Saccharomyces cerevisiae) supplementation in the diet of lambs fed with two different concentrate proportions on voluntary intake of DM, apparent digestibility coefficients of nutrients, nitrogen balance, in vitro digestibility of dry matter of diets and rumen fermentative parameters.

\section{MATERIALS AND METHODS}

The study was carried out at Instituto de Zootecnia, city of Nova Odessa, located in São Paulo State, Brazil. The lambs were fed with isoproteic diets according to [7] composed of grass hay, chopped into particles of approximately $3 \mathrm{~cm}$, and concentrate based on corn, soybean meal, mineral mixture, and limestone (Table 1). Two concentrate rations were prepared, varying the proportion of ingredients in order to maintain the diets isoproteic on the two different treatments ( 80 and $60 \%$ of concentrate). 
The diets were composed of two different proportions of concentrate on dry matter basis (60 or 80\%), supplemented with $5 \mathrm{~g} /$ day of active yeast (Saccharomyces cerevisiae, strain 1026, Yea Sacc ${ }^{\circledR}$ 1026, Alltech. Inc.) with viable cells concentration of $1 \times 10^{8} \mathrm{CFU} / \mathrm{g}$, added to the concentrate rations.

Twenty non-castrated wool lambs were used to apparent digestibility, with approximately 120 days of age and live weight of $33.84 \pm 5.98 \mathrm{~kg}$. They were housed in metabolism crates, with collector of feces and urine, during 26 days, with ten days for diet adaptation, followed by eight days to measure ad libitum voluntary intake and eight days for total feces and urine collection, in order to calculate apparent digestibility coefficients of dry matter (DM), organic matter (OM), crude protein (CP), neutral detergent fiber (NDF), acid detergent fiber (ADF), ether extract (EE), hemicellulose (HEM), cellulose (CEL) and non-fibrous carbohydrate (NFCHO). The TDN $(\%)$ value was calculated as the sum of digestible nutrients.

In the period of voluntary intake measurement, the intended relation concentrate : roughage was achieved through daily adjust of concentrate and hay based on refusals of previous day and assuring no concentrate refusal and hay refusal around $15 \%$ to guarantee maximum intake. After this period, the mean daily intake was calculated and the animals were restricted to $90 \%$ of this value for eight days. In the third day after diet restriction, total production of feces and urine was measured along six days. Total fecal output was recorded daily, and $10 \%$ aliquot taken, composited by animal and frozen. Urine was collected in plastic buckets containing five $\mathrm{ml}$ of $1: 1$ water and chloridic acid solution and total volume was recorded every morning with $10 \%$ taken, composite by animal and frozen.

The statistical analyses were performed by randomized block design, in a $2 \times 2$ (two concentrate proportions, presence or absence of active yeast) factorial arrangements, with five animals per treatment.

Four adult male sheep with rumen cannulas in their rumens to evaluate rumen parameters, housed in individual pens for 45 days were used. Animals were fed with hay and concentrate (Table 1) according to the treatments described above. Five gram of commercial active yeast Saccharomyces cerevisiae, strain Yea Sacc 1026® (Alltech. Inc) was wrapped in paper and introduced into the rumen of each animal, every day and always in the morning. After a ten days period of treatment adaptation, rumen liquid collection was performed on the eleventh day, in five different times: before feeding (0) and 2, 4, 6 and 8 hours after feeding. After this period, treatments were changed and another ten days of diet adaptation was accomplished. Rumen fluid was collected and $\mathrm{pH}$ red immediately. Ammonia $\left(\mathrm{NH}_{3}\right)$ concentration was assessed in accordance to the procedures described at [8] in a centrifuged sample.

The statistical analysis was performed using a Latin square design in factorial scheme $(2 \times 2)$ with four repetitions per treatment.

Table 1. Ingredient proportion in concentrate rations and chemical composition of diets.

\begin{tabular}{|c|c|c|c|}
\hline \multirow[t]{2}{*}{ Ingredients } & $\begin{array}{l}\text { Concentrate rations } \\
\text { (treatment with } 80 \% \text { ) }\end{array}$ & $\begin{array}{l}\text { Concentrate rations } \\
\text { (treatment with } 60 \% \text { ) }\end{array}$ & \multirow[t]{2}{*}{ Hay } \\
\hline & Ingredients Proportion (\%) & Ingredients Proportion (\%) & \\
\hline Corn & 76.2 & 71.4 & - \\
\hline Soybean Meal & 21.0 & 25.0 & - \\
\hline Mineral mixture* & 0.9 & 1.3 & - \\
\hline Sodium Chloride & 0.5 & 0.7 & - \\
\hline Limestone & 1.4 & 1.6 & - \\
\hline \multicolumn{4}{|c|}{ Chemical Composition } \\
\hline $\mathrm{DM}(\%)$ & 84.90 & 84.68 & 87.64 \\
\hline $\mathrm{CP}(\%)$ & 18.70 & 20.50 & 8.91 \\
\hline $\mathrm{EE}(\%)$ & 3.20 & 2.60 & 1.50 \\
\hline $\operatorname{NDF}(\%)$ & 17.96 & 20.38 & 78.38 \\
\hline $\mathrm{ADF}(\%)$ & 4.06 & 3.82 & 38.30 \\
\hline MM (\%) & 4.50 & 6.20 & 6.10 \\
\hline $\operatorname{Hem}(\%)$ & 62.95 & 57.79 & 40.09 \\
\hline
\end{tabular}

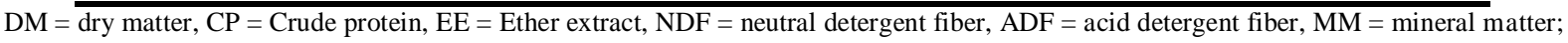
Hem $=$ hemicellulose.

* Composition of product: calcium 120 g / kg, Phosphorus 87 g / kg, sodium 147 g / kg; Sulfur 18 g / kg, Copper 590 mg / kg; Cobalt 40 mg / kg, Chromium $20 \mathrm{mg} / \mathrm{Kg}$, Iron $1800 \mathrm{mg} / \mathrm{kg}$, Iodine $80 \mathrm{mg} / \mathrm{kg}$, Manganese $1300 \mathrm{mg} / \mathrm{kg}$, Selenium $15 \mathrm{mg} / \mathrm{kg}$, Zinc $3800 \mathrm{mg} / \mathrm{kg}$; Molybdenum $300 \mathrm{mg} / \mathrm{kg}$; Fluorine (max. ) $870 \mathrm{mg} / \mathrm{kg}$. 
In vitro digestibility of dry matter (IVDDM) of the two diets (80:20 and 60:40) was performed with rumen fluid from four rumen cannulated sheep. Five grams of paper wrapped active yeast was introduced into rumen through the rumen cannula, in the morning, before feeding, only in two animals. Rumen fluids were collected one hour after introduction of active yeast in the rumen, before animals were first fed.

Samples were incubated with rumen fluid for each treatment (with or without active yeast), plus McDougall buffer solution, in a glass tube, for 48 hours, in water bath at $39^{\circ} \mathrm{C}$, according to the methodology described by [9] and based on the works by [10] and [11].

Statistical analysis was performed on a completely randomized design in factorial scheme $(2 \times 2)$ with 10 repetitions per treatment.

\section{RESULTS AND DISCUSSION}

Supplementation with active yeast led to a significant increase $(\mathrm{P}<0.05)$ on apparent digestibility coefficients of DM, OM, CP NDF, HEM and Non-fibrous CHO (Table 2), independently of concentrate proportion and agree with [5]. Active yeast probably provided better conditions in rumen environment, with stimuli to growth of bacteria responsible for food digestion [3, 4, 2]. As the interaction between the two factors (active yeast $X$ diets) was not statistically significant it means that the effect of active yeast supplementation was effective on the two diets, independently of their concentrate proportion. It is known that active yeast can improve rumen environment, meanly keeping $\mathrm{pH}$ values around neutrality [4] and avoiding drastic drop in diets with high concentrate proportion. These results highlight its effect on moderate concentrate diets as well. These results were similar to those by [5] and [12], who also found increase on apparent digestibility coefficients with active yeast supplementation. The ADCEE, ADCADF and ADCCEL and nitrogen balance were not modified by active yeast supplementation on both diets.

Table 2. Least squares means and standard error (S.E.) for apparent digestibility coefficient (ADC), DM intake and nitrogen balance of lambs fed diets containing different concentrate proportions with absence or presence of active yeast.

\begin{tabular}{|c|c|c|c|c|c|c|c|}
\hline \multirow[t]{2}{*}{ Variables } & \multicolumn{2}{|c|}{$\begin{array}{c}\text { Concentrate } \\
\text { Proportion }(\%)\end{array}$} & \multirow{2}{*}{$\mathrm{P}>\mathrm{F}$} & \multicolumn{2}{|c|}{ Active yeast } & \multirow{2}{*}{$\mathrm{P}>\mathrm{F}$} & \multirow{2}{*}{ S.E. } \\
\hline & 80 & 60 & & Absence & Presence & & \\
\hline ADC DM & 79.78 & 76.42 & 0.0075 & 76.86 & 79.35 & 0.0352 & 0.74 \\
\hline $\mathrm{ADC} O \mathrm{OM}$ & 80.70 & 77.25 & 0.0068 & 77.80 & 80.15 & 0.0469 & 0.75 \\
\hline ADC PC & 75.66 & 75.08 & 0.6838 & 73.88 & 76.87 & 0.0524 & 0.98 \\
\hline ADC EE & 90.52 & 88.82 & 0.0482 & 89.40 & 89.93 & 0.5034 & 0.54 \\
\hline ADC NDF & 58.40 & 64.15 & 0.0269 & 58.55 & 63.99 & 0.0344 & 1.61 \\
\hline ADC ADF & 63.28 & 64.70 & 0.4254 & 62.99 & 64.99 & 0.2690 & 1.21 \\
\hline ADC CEL & 70.97 & 72.54 & 0.3889 & 70.63 & 72.88 & 0.2246 & 1.24 \\
\hline ADC HEM & 54.36 & 63.62 & 0.0304 & 54.87 & 63.11 & 0.0497 & 2.67 \\
\hline ADC NFCHO & 79.78 & 76.42 & 0.0075 & 76.86 & 79.35 & 0.0352 & 0.74 \\
\hline TDN & 72.73 & 70.21 & 0.0838 & 69.85 & 73.10 & 0.0320 & 0.95 \\
\hline DM intake (kg/day) & 1.29 & 1.17 & 0.1193 & 1.25 & 1.21 & 0.5863 & 0.05 \\
\hline Retained N (g/day) & 11.42 & 9.85 & 0.3778 & 11.10 & 10.17 & 0.5968 & 1.21 \\
\hline
\end{tabular}

As result of the increased digestible coefficient of these nutrients, the TDN values was also increased significantly $(\mathrm{P}<0.05)$ in diets with the active yeast. The active yeast supplementation increased TDN value as a result of augment of digestibility coefficient of CP, NDF and Non-fibrous CHO, since it was calculated using the sum of the digestible components. This result shows that the use of active yeast improves feed energy availability for animal and can be used for enhancing animal performance. These results are similar to those obtained by [13], who found higher TDN values when adding S. cerevisiae to cattle diet. However [14] did not report differences in TDN values when supplementing cattle diets with active yeast.

Supplementation with S. cerevisiae and levels of concentrate in diet did not influence retained nitrogen amounts, although increased the digestibility coefficient of CP. Similar results were reported by [15] who also did not find significant difference for nitrogen balances, when worked with sheep fed with two proportions of concentrate $(60 \%$ and $30 \%)$.

The diet with $80 \%$ of concentrate showed higher $(\mathrm{P}<0.05)$ apparent digestibility coefficients of dry matter (ADCDM), organic matter (ADCOM), ether extract (ADCEE) and non-structural carbohydrates (ADCNSC) and lower coefficients of neutral detergent fiber (ADCNDF) and hemicelluloses (ADCHEM) than the diet with $60 \%$ of concentrate (Table 2). The apparent digestibility coefficient of crude protein (ADCCP) did 
not differ significantly ( $>0.05$ ) between the two diets (Table 2). The effect of high concentrate levels on depression of fiber digestibility is well known [16].

Active yeast did not affect $(\mathrm{P}>0.05)$ voluntary intake, independently of the concentrate proportion and the interaction between factors (yeast supplementation $\mathrm{X}$ concentrate proportion) was not significant $(\mathrm{P}>0.05)$. There was not a diet effect (concentrate proportion) for DM intake, as well. The increased DM and OM digestibility was not sufficient to modify DM intake by active yeast supplementation since is well known that intake is strongly related to DM digestibility [16]. The values for DM intake can be considered satisfactory, however, are slightly below recommendation of [7].

The diets with higher concentrate proportion had greater IVDDM values and addition of active yeast resulted on increased value $(\mathrm{P}=0.066)$, regardless of concentrate proportion (Table 3). Positive results for IVDDM in diets with different concentrates proportion with addition of active yeast were also achieved by [17].

Table 3. Values for in vitro DM digestibility (\%) of diets with different concentrate proportions with or without active yeast.

\begin{tabular}{llccc}
\hline & & $\begin{array}{c}\text { IVDDM } \\
(\boldsymbol{\%})\end{array}$ & P & C.V. \\
\hline \multirow{2}{*}{ Diets } & $80 \%$ concentrate & 85.08 & $<0.0001$ \\
\hline \multirow{2}{*}{ Active yeast } & Without & 70.92 & & \\
& With & 76.84 & \multirow{2}{*}{0.0666} & \\
\hline
\end{tabular}

The active yeast supplementation did not affect $(\mathrm{P}>0.05)$ values of rumen $\mathrm{pH}$ neither on the lower nor on the higher concentrate proportion but showed diet effect since was lower in the higher concentrate proportion (Table 4). The average rumen $\mathrm{pH}$ increased linearly $(\mathrm{P}<0.001)$ along collection times, from a 5.88 value immediately before feeding ( 0 hour) to 6.14 after six hours from feeding, with maximum value (6.28) eight hours after feeding. The range of $\mathrm{pH}$ values in the diet with $60 \%$ of concentrate (from $\mathrm{pH} 6.10$ to 6.41) was much narrower than that for the diet with $80 \%$ of concentrate (5.62 and 6.14, 2 hours and 8 hours after feeding, respectively).

Table 4. Rumen $\mathrm{pH}$ of cannulated sheep fed diets containing different concentrate proportions with or without active yeast on different collection times and regression

\begin{tabular}{|c|c|c|c|c|c|c|c|c|c|c|}
\hline \multirow[t]{2}{*}{ Diets } & \multicolumn{4}{|c|}{ Time (h) } & \multirow{2}{*}{\multicolumn{2}{|c|}{ Means }} & \multirow[t]{2}{*}{ S.E. } & \multicolumn{3}{|c|}{$\mathrm{P}>\mathrm{F}$} \\
\hline & 0 & 2 & 4 & 6 & & & & L.R. & Q.R. & C.R. \\
\hline With yeast & 5.86 & 5.89 & 5.82 & 6.10 & 6.29 & $5.99 \mathrm{a}$ & 0.03 & & & \\
\hline Without yeast & 5.89 & 5.86 & 5.99 & 6.18 & 6.27 & $6.04 \mathrm{a}$ & 0.05 & & & \\
\hline $80 \%$ concentrate & 5.65 & 5.62 & 5.78 & 6.02 & 6.14 & $5.84 \mathrm{~b}$ & 0.03 & & & \\
\hline $60 \%$ concentrate & 6.10 & 6.13 & 6.03 & 6.27 & 6.41 & $6.19 \mathrm{a}$ & 0.03 & & & \\
\hline Means & 5.88 & 5,88 & 5.91 & 6.14 & 6.28 & & & $<0.001$ & 0.009 & 0.344 \\
\hline S.E. & 0.05 & 0.05 & 0.05 & 0.05 & 0.05 & & & & & \\
\hline
\end{tabular}

L. R. - linear regression Q. R.-quadratic regression and C. R - cubic. Means followed by same letters do not differ by $\mathrm{F}$ test (P>0.05).

It was expected that the improvement on apparent digestibility coefficients as well as, IVDDM were caused by increase on rumen $\mathrm{pH}$, since cellulolytic bacteria growth is stimulated by maintenance of stable $\mathrm{pH}$ [16]. The $\mathrm{pH}$ values were maintained on majority of time on the physiological range between 5.7 to 7.4 , considered as normal by [7], but the $80 \%$ concentrate diet reached values below 5.7 and that can impair fiber digestibility. One of the expected mechanisms of action of active yeast is to decrease rumen oxygen content and increase of $\mathrm{CO}_{2}$ concentration into rumen. However, the rumen parameters evaluation was not performed on the same animals used for apparent digestibility assessment but in cannulated ones, in which rumen environment was exposed to oxygen due to frequent opening of cannulas. So this collection methodology may not be efficient on this case and can explain why did not show effect. These results are similar to those found by [13] and [18] that did not observe significant statistical differences in rumen $\mathrm{pH}$ of cattle supplemented with active yeast.

Rumen ammonia concentration was not affected by proportions of concentrate on the diets or by the addition of active yeast (Table 5) and showed a linear decrease through the collection times with highest value 2 hours after feeding. The values were much higher than the minimum value of $13 \mathrm{mg} / 100 \mathrm{~mL}$ which, according to [16], could affect availability of nitrogen for microorganisms and impair intake and fiber digestibility. These results are similar to those found by [19] who worked with addition of S. cerevisiae in diet of cattle fed with 
grass hay and increasing levels of leucena, and also observed increase in rumen ammonia concentrations 2 hours after feeding, with constant decline until eight hours after feeding, returning to values close to time zero.

According to [7], although the ideal rumen ammonia concentration for optimal microbial growth is not clearly defined, values above 5 to $10 \mathrm{mg} / 100 \mathrm{~mL}$ have no effect in the production of microbial protein. High values of ammonia concentration found in the present study occurred, probably, due to high percentages of crude protein in diets and, also, due to the fact that ammonia is mainly used for the growth of fiber digesting microorganisms [7], thus, since it was a rich concentrate diet, great part of the population was constituted of amylolytic microorganisms which prefer aminoacids or peptides for microbial protein synthesis. [20] and [4] also did not found any effect of active yeast supplementation on the levels of rumen $\mathrm{N}-\mathrm{NH}_{3}$ on cattle diets.

Table 5. Rumen Ammonia nitrogen $(\mathrm{mg} / 100 \mathrm{~mL})$ of cannulated sheep fed diets containing different concentrate proportions with or without active yeast on different collection times and regression.

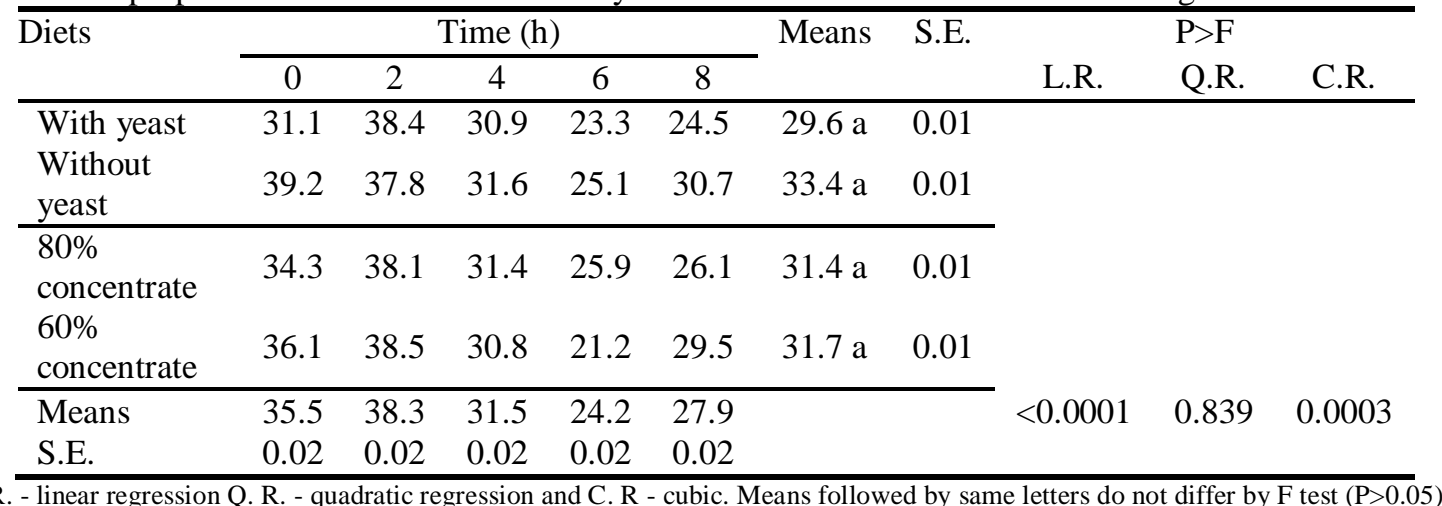

\section{CONCLUSION}

The addition of active yeast in lamb diets improves digestibility of nutrients, regardless of concentrate proportion, without changing DM intake. However, it was not possible to clearly determine the action mechanism of the probiotic in rumen environment, since supplementation with yeast did not alter nor $\mathrm{pH}$ neither ammonia nitrogen concentrations.

\section{Acknowledgements}

FAPESP (Fundação de Amparo à Pesquisa do Estado de São Paulo) for financial support (nº 2008/06201-0).

\section{REFERENCES}

[1] S. Khampa and M. Wanapat, Manipulation of Rumen Fermentation with Organic Acids Supplementation in Ruminants Raised in the Tropics, Pakistan Journal of Nutrition, 6, 2007, 20-27.

[2] P. Mossoni, F. Chaucheyras-Durand, C. Béra-Maillet and E. Forano, Quantification by real-time PCR of cellulolyticbacteria in the rumen of sheep after supplementation of forage diet with readily fermentable carbohydrate: effect of a yeast additive, Journal of Applied Microbiology, 103, 2007, 2676-2685.

[3] G. Fonty and F. Chaucheyras-Durand, Effects and modes of action of live yeasts in the rumen. Biologia (Bratislava), 61, 2006, 741-750.

[4] C.M. Guedes, D. Gonçalves, M.A.M. Rodrigues and A. Dias-da-Silva, Effects of a Saccharomyces cerevisiae yeast on ruminal fermentation and fiber degradation of maize silages in cows, Animal Feed Science and Technology, 145 (1-4), 2008, 2740.

[5] S.G. Haddad and S.N. Goussous, Effect of yeast culture supplementation on nutrient intake, digestibility and growth performance of Awassi lambs, Animal Feed Science and Technology, 118, 2005, 343-348.

[6] J. Sales, Effects of Saccharomyces cerevisiae supplementation on ruminal parameters, nutrient digestibility and growth in sheep: A meta-analysis, Small Ruminant Research, 100, 2011, 19-29.

[7] National Research Council (NRC), Nutrient requirements of sheep (Washington: National Academies Press, 2007).

[8] H. Fenner, Method for determining total volatile bases in rumen fluid by steam destilation, Journal Dairy Science, 48, 1965, 249251.

[9] D.J. Silva and A.C. Queiroz, Análises de alimentos: métodos químicos e biológicos (Editora UFV- Universidade Federal de Viçosa, 2002).

[10] J.M.A. Tilley and R.A. Terry, A two-stage technique for the in vitro digestion of forage crops, Joumal of the British Grassiand Society, 18, 1963, 104-111.

[11] B.R. Baumgardt, J.L. Cason and M.W. Taylor, Evaluation of forages in the laboratory: Comparative accuracy of several methods, Journal of Dairy Science, 45, 1962, 59-61.

[12] A.M.A. Fadel Elseed, Rania and M.A. Abusamra, Effects of supplemental yeast (Saccharomyces cerevisiae) culture on ndf digestibility and rumen fermentation of forage sorghum hay in Nubian goat's kids, Research Journal of Agriculture and Biological Sciences, 3, 2007, 133-137.

[13] F. Fereli, A.F. Branco, C.C. Jobim, S.M. Coneglian, F. Granzotto and J.C. Barreto, Monensina sódica e Saccharomyces cerevisiae em dietas para bovinos: fermentação ruminal, digestibilidade dos nutrientes e eficiência de síntese microbiana, Revista Brasileira de Zootecnia, 39, 2010, 183-190. 
[14] R.C. Queiroz, A.F. Bergamaschine, J.F.P. Bastos, P.C. Santos and G.C. Lemos, Uso de produto à base de enzima e levedura na dieta de bovinos: Digestibilidade dos nutrientes e desempenho em confinamento, Revista Brasileira de Zootecnia 33, 2004, 15481556.

[15] G.F. Mouro, A.F. Branco, D.L. Harmon, L.P. Rigolon and S.M. Coneglian, Fontes de carboidratos e porcentagem de volumosos em dietas para ovinos: balanço de nitrogênio, digestibilidade e fluxo portal de nutrientes, Revista Brasileira de Zootecnia, 36, 2007, 489-498.

[16] P. Van Soest, Nutritional ecology of the ruminan (Ithaca: Cornell University Press, 1994).

[17] J.R.F. Beleze, L.M. Zeoula, J. Guido, S.L. Candêo Filho, K. Ricardo and M.C. de Paula, Aditivos vs teores de concentrado na ração de bubalinos e bovinos: digestibilidade in vitro da matéria seca, Acta Science Animal Science, 29, 2007, 417-424.

[18] A.R. Rivera, T.T. Berchielli, J.D. Messana, P.T. Velasquez, A.V.M. Franco and L.B. Fernandes, Fermentação ruminal e produção de metano em bovinos alimentados com feno de capim Tifton-85 e concentrado com aditivos, Revista Brasileira de Zootecnia, 39 , 2010, 617-624.

[19] R.A. Possenti, R. Raul Franzolin, E.A. Schammas, J.J.A.A. Demarchi, R.T.S. Frighetto and M.A. Lima, Efeitos de dietas contendo Leucaena leucocephala e Saccharomyces cerevisiae sobre a fermentação ruminal e a emissão de gás metano em bovinos, Revista Brasileira de Zootecnia, 37, 2008, 1509-1516.

[20] G.L. Franco, R.F. Ferreira, M.T. Rocha, C.S.S. Cysneiros and J.M.S. Diogo, Parâmetros ruminais e desaparecimento da matéria seca e fibra em detergente neutro da forragem em bovinos que recebendo levedura e enzimas fibrolíticasna dieta, Revista Brasileira de Saúde e Produção Animal, 9, 2008, 488-496. 